UDC 332

Submitted: 28.10 .2018

LBC 65.04

Accepted: 15.11 .2018

\title{
CONDITIONS FOR SCIENTIFIC COMMUNICATIONS AND COLLABORATIONS IN THE RUSSIAN FEDERATION'S REGIONS
}

\author{
Natalya E. Barsukova \\ Tver State University, Tver, Russian Federation \\ Elena V. Klyushnikova \\ Tver State University, Tver, Russian Federation \\ Anna A. Maltseva \\ Tver State University, Tver, Russian Federation \\ Nadezhda N. Bedenko \\ Tver State University, Tver, Russian Federation
}

\begin{abstract}
The subject of research within the framework of this article is the current state of the Russian Federation's regions in terms of the created conditions for cooperation between research teams and the commercialization of scientists' results of intellectual activity.

The paper's goal is to identify the potential and results of the regional environment, which promotes effective scientific activity in the field of communications and collaborations between researchers and practical application of scientific results in the field of economy and social sphere, on the basis of indicators system.

The authors made an analysis of the estimated indicators, as well as the calculation of the integral index characterizing the conditions of the regional environment that are under study. The method chosen in the work includes the separation of the indicators selected for analysis into indicators of potential and result, as well as the N standard calculation of the integral indicator by the distance method. Relative indicators were used in calculating the integral indicator to ensure comparability of data from different regions.

Among the estimated indicators in the study are the number of created clusters; technology parks; innovative activity of organizations; the number of created small innovative enterprises; number of winners of the program of megagrants; competition for the development of cooperation of Russian universities, scientific institutions and manufacturing enterprises; indicator of the number of potentially commercialized patents.

The obtained integral characteristics make it possible to draw conclusions about the complex state of conditions in regions that promoting scientific activity, to identify the leading regions that can become benchmarks. Separate regional initiatives are highlighted in the work.

The resulting conclusions can form the basis for the development of a regional environment that promotes scientific activity, based on the development of measures to introduce the best initiatives of the leading regions into practice.

Key words: communications, collaboration, science, research and development, region, commercialization.

Citation. Barsukova N.E., Klyushnikova E.V., Maltseva A.A., Bedenko N.N. Conditions for Scientific Communications and Collaborations in the Russian Federation's Regions. Vestnik Volgogradskogo gosudarstvennogo universiteta. Seriya 3, Ekonomika. Ekologiya [Science Journal of Volgograd State University. Global Economic System], 2018, vol. 20, no. 4, pp. 65-76. (in Russian). DOI: https://doi.org/10.15688/jvolsu3.2018.4.7
\end{abstract}




\title{
УСЛОВИЯ ДЛЯ НАУЧНЫХ КОММУНИКАЦИЙ И КОЛЛАБОРАЦИЙ В РЕГИОНАХ РОССИЙСКОЙ ФЕДЕРАЦИИ
}

\author{
Наталья Евгеньевна Барсукова \\ Тверской государственный университет, г. Тверь, Российская Федерация \\ Елена Валерьевна Клюшникова \\ Тверской государственный университет, г. Тверь, Российская Федерация \\ Анна Андреевна Мальцева \\ Тверской государственный университет, г. Тверь, Российская Федерация \\ Надежда Николаевна Беденко \\ Тверской государственный университет, г. Тверь, Российская Федерация
}

\begin{abstract}
Аннотация. Предметом исследования в рамках данной статьи является современное состояние регионов Российской Федерации в части созданных условий для сотрудничества исследовательских коллективов в процессе коммерциализации результатов интеллектуальной деятельности.

Цель работы - на основе системы показателей выявить потенциал и результаты региональной среды, содействующей эффективной научной деятельности в части коммуникаций и коллабораций между исследователями и практического внедрения научных результатов в отрасли экономики и социальной сферы.

Авторами проведен анализ оценочных показателей, а также представлен расчет интегрального индекса, характеризующего изучаемые условия региональной среды. Выбранная в работе методика включает разделение выбранных для анализа показателей на индикаторы потенциала и результата, а также стандартный расчет интегрального показателя методом расстояний. В расчете интегрального показателя были использованы относительные показатели для обеспечения сопоставимости данных различных регионов.

К числу оценочных показателей в рамках исследования отнесены количество созданных кластеров, технопарков; инновационная активность организаций; число созданных малых инновационных предприятий; количество победителей программы мегагрантов; конкурса по развитию кооперации российских вузов, научных учреждений и производственных предприятий; индикатор числа потенциально коммерциализируемых патентов.

Полученные интегральные характеристики позволяют сделать выводы о комплексном состоянии в регионах условий, содействующих научной деятельности, выделить регионы-лидеры, которые могуг стать бенчмарками. Отдельные региональные инициативы выделены в работе.

Полученные в результате выводы могут стать основой для развития региональной среды, содействующей научной деятельности, на основе разработки мероприятий по внедрению в практику лучших инициатив регионов-лидеров.
\end{abstract}

Ключевые слова: коммуникации, коллаборации, наука, исследования и разработки, регион, коммерциализация.

Цитирование. Барсукова Н. Е., Клюшникова Е. В., Мальцева А. А., Беденко Н. Н. Условия для научных коммуникаций и коллабораций в регионах Российской Федерации // Вестник Волгоградского государственного университета. Серия 3, Экономика. Экология. - 2018. - Т. 20, № 4. - С. 65-76. - DOI: https://doi.org/ 10.15688/jvolsu3.2018.4.7

Актуальность исследования вопросов развития науки обусловлена бесспорными приоритетами, которые выделены в ключевых стратегических документах страны: Стратегии научно-технологического развития Российской Федерации, Указе Президента Рос- сийской Федерации № 204 от 7 мая 2018 г. «О национальных целях и стратегических задачах развития Российской Федерации на период до 2024 года» и ряде других.

В последнем документе, в частности, отмечается необходимость ускорения тех- 
нологического развития Российской Федерации, увеличение количества организаций, осуществляющих технологические инновации, до $50 \%$ от их общего числа [14]. К числу первоочередных задач, возложенных на Правительство Российской Федерации, отнесены вопросы создания конкурентоспособных научных коллективов и лабораторий, в том числе международных, формирование системы кооперации с организациями, действующими в реальном секторе экономики, интеграции университетов и научных организаций и др.

Именно эффективные формы сотрудничества в научной сфере, вовлечение в научно-техническую деятельность максимального числа заинтересованных сторон в рамках реализации совместных проектов способны обеспечить дополнительный эффект синергии от взаимодействия, а также выявить те приоритеты исследований и разработок, которые способны быть реализованы на практике.

Комплексное изучение вопросов научных коллабораций и коммерциализации исследований и разработок обусловлено формулировками, заложенными в Стратегии научно-технологического развития Российской Федерации. Блок задач «Взаимодействие и кооперация» предполагает формирование эффективной системы коммуникации в области науки, технологий и инноваций, повышение восприимчивости экономики и общества к инновациям, развитие наукоемкого бизнеса [13].

Целью данной работы является комплексная оценка вопросов взаимодействия и кооперации в научно-технической сфере, в том числе направленного на коммерциализацию результатов интеллектуальной деятельности в регионах Российской Федерации.

Вопросы коллабораций в научно-технической сфере активно исследуются в литературе. Достаточно глубоко вопросы дефиниций и классификаций различных форм коллабораций рассмотрены в работе Ю.Ш. Коробкиной, А.М. Омельченко [4]. Авторы описывают ключевые характеристики коллабораций, используя подходы, характеризующие их различные аспекты:

- ресурсный - заключается в наличии у организации особых ресурсов, необходимых для вступления в ту или иную коллаборацию;
- организационный - ключевые организационные характеристики коллаборационной деятельности;

- процессный - определение и реализация ключевых процессов, правил, согласований, которые происходят в процессе коллаборации;

- компетентностный - обеспечение обмена явными и неявными знаниями в процессе коллаборации, что обеспечивает формирование в том числе междисциплинарных компетенций;

- экосистемный - обмен информацией и самообучение социально-экономических систем с возникновением синергетического эффекта.

В работе также выделяются коллаборации микроуровня (организационного, системного) и наноуровня (отдельных субъектов взаимодействий).

При этом в исследовании Фонда «ЦСР» «Перспективы развития России в международных научных коллаборациях» [12] выделяются особенности современных коллабораций, которые не в полной мере встраиваются в предложенные классификационные рамки. Так, второе поколение международных исследовательских коллабораций предполагает дробление и распределение научной задачи для максимально быстрого и глубокого изучения научной проблемы, в отличие от первого поколения, которое основывалось, по мнению авторов, преимущественно на ресурсном подходе.

В качестве преобладающей формы сотрудничества выделятся кооперация малых научных коллективов наряду с большими научными институтами, вузами и организациями, что представляет собой интегрированные взаимосвязи микро- и наноуровня.

В рамках формирования теоретической рамки исследования были выделены показатели, характеризующие потенциал субъектов Российской Федерации в части развития условий для коммуникаций и коллабораций между исследователями, коммерциализации исследований и разработок, а также достигнутых результатов, характеризующих соответствующий потенциал (см. табл. 1). Выбор показателей осуществлялся на основе критериев их полноты, доступности и соответствия выбранному предмету исследования. 


\section{Оценочные показатели условий для коммуникаций и коллабораций между исследователями, коммерциализации исследований и разработок в регионах Российской Федерации}

\begin{tabular}{|c|c|c|c|}
\hline $\begin{array}{c}\text { Наименование } \\
\text { показателя }\end{array}$ & Методика расчета & $\begin{array}{l}\text { Период } \\
\text { расчета }\end{array}$ & $\begin{array}{c}\text { Информационный } \\
\text { источник }\end{array}$ \\
\hline \multicolumn{4}{|c|}{ Показатели потенцииала } \\
\hline $\begin{array}{l}\text { Количество созданных } \\
\text { кластеров }\end{array}$ & $\begin{array}{l}\text { Число кластеров, зарегистри- } \\
\text { рованных в официальной базе } \\
\text { данных Минобрнауки России }\end{array}$ & \multirow[t]{2}{*}{$\begin{array}{l}\text { На момент прове- } \\
\text { дения исследова- } \\
\text { ния (март } 2018 \text { г.) }\end{array}$} & \multirow{2}{*}{$\begin{array}{l}\text { Официальный сайт Нацио- } \\
\text { нального центра по монито- } \\
\text { рингу инновационной ин- } \\
\text { фраструктуры научно- } \\
\text { технической деятельности и } \\
\text { инновационных систем } \\
\text { (http://www.miiris.ru/) }\end{array}$} \\
\hline $\begin{array}{l}\text { Количество созданных } \\
\text { технопарков }\end{array}$ & $\begin{array}{l}\text { Число технопарков, зарегист- } \\
\text { рированных в официальной } \\
\text { базе данных Минобрнауки } \\
\text { России }\end{array}$ & & \\
\hline \multicolumn{4}{|c|}{ Показатели результата } \\
\hline $\begin{array}{l}\text { Инновационная актив- } \\
\text { ность организаций }\end{array}$ & $\begin{array}{l}\text { Отношение числа организа- } \\
\text { ций, осуществлявших техно- } \\
\text { логические, организационные } \\
\text { или маркетинговые иннова- } \\
\text { ции, к общему числу обследо- } \\
\text { ванных за определенный пе- } \\
\text { риод времени организаций в } \\
\text { регионе }\end{array}$ & 2016 г. & $\begin{array}{l}\text { Официальный сайт Феде- } \\
\text { ральной службы государст- } \\
\text { венной статистики } \\
\text { (http://www.gks.ru/) }\end{array}$ \\
\hline $\begin{array}{l}\text { Число созданных ма- } \\
\text { лых инновационных } \\
\text { предприятий (МИП) }\end{array}$ & $\begin{array}{l}\text { Количество МИП, учтенных в } \\
\text { официальной базе данных } \\
\text { Минобрнауки России }\end{array}$ & $\begin{array}{l}\text { На момент прове- } \\
\text { дения исследова- } \\
\text { ния (март } 2018 \text { г.) }\end{array}$ & $\begin{array}{l}\text { Официальный сайт «Учет и } \\
\text { мониторинг малых иннова- } \\
\text { ционных предприятий науч- } \\
\text { но-образовательной сферы» } \\
\text { (https://mip.extech.ru/) }\end{array}$ \\
\hline $\begin{array}{l}\text { Количество победите- } \\
\text { лей программы мега- } \\
\text { грантов }\end{array}$ & $\begin{array}{l}\text { Совокупное количество побе- } \\
\text { дителей конкурсов мегагран- } \\
\text { тов, проводимых в соответст- } \\
\text { вии с Постановлением Прави- } \\
\text { тельства Российской Федера- } \\
\text { ции № } 220\end{array}$ & $\begin{array}{l}\text { За весь период } \\
\text { проведения кон- } \\
\text { курса }\end{array}$ & $\begin{array}{l}\text { Официальный сайт «Мега- } \\
\text { гранты» (http://www.p220.ru/) }\end{array}$ \\
\hline $\begin{array}{l}\text { Количество победите- } \\
\text { лей конкурса по раз- } \\
\text { витию кооперации } \\
\text { российских вузов, на- } \\
\text { учных учреждений и } \\
\text { производственных } \\
\text { предприятий }\end{array}$ & $\begin{array}{l}\text { Совокупное количество побе- } \\
\text { дителей конкурсов по разви- } \\
\text { тию кооперации российских } \\
\text { вузов, научных учреждений и } \\
\text { производственных предпри- } \\
\text { ятий, проводимых в соответ- } \\
\text { ствии с Постановлением Пра- } \\
\text { вительства Российской Феде- } \\
\text { рации № } 218\end{array}$ & $\begin{array}{l}\text { За весь период } \\
\text { проведения кон- } \\
\text { курса }\end{array}$ & $\begin{array}{l}\text { Официальный сайт «Разви- } \\
\text { тие кооперации российских } \\
\text { вузов, научных учреждений } \\
\text { и производственных пред- } \\
\text { приятий» } \\
\text { (http://www.p218.ru/) }\end{array}$ \\
\hline $\begin{array}{l}\text { Индикатор числа по- } \\
\text { тенциально коммер- } \\
\text { циализируемых патен- } \\
\text { тов }\end{array}$ & $\begin{array}{l}\text { Показатель представляет со- } \\
\text { бой сумму числа полученных } \\
\text { российских патентов с коэф- } \\
\text { фициентом } 0,08 \text { и РСТ- } \\
\text { патентов с коэффициентом } \\
0,5 \text { [15] }\end{array}$ & 2016 г. & $\begin{array}{l}\text { Официальный сайт Феде- } \\
\text { ральной службы государст- } \\
\text { венной статистики } \\
\text { (http://www.gks.ru/); } \\
\text { Федеральная система мони- } \\
\text { торинга научных организаций } \\
\text { (http://www.sciencemon.ru/) }\end{array}$ \\
\hline
\end{tabular}

Примечание. Составлено авторами.

Развитие кооперации образовательных, научных и промышленных организаций региона может быть обеспечено на базе различных информационно-коммуникационных площадок. Перспективными для развития кооперации инфраструктурными образованиями являются кластеры и технопарки.

Так, кластеры выделяются в работе Н.В. Смородинской как сетевые инновационные экосистемы особого класса, которые включают в себя широкий круг независимых 
агентов разного профиля, взаимодействующих друг с другом в режиме непрерывных согласований, опираясь на сетевые платформы или иные институты поддержки коллаборации [11]. Технопарки как интегрированные элементы инновационной инфраструктуры также создают условия для реализации кооперации и сотрудничества в рамках реализации научнотехнической и инновационной деятельности резидентов.

Анализ данных официального сайта Национального центра по мониторингу инновационной инфраструктуры научно-технической деятельности и инновационных систем позволил установить количество кластеров и технопарков в каждом субъекте Российской Федерации.

Данные о количестве инновационных территориальных кластеров, полученные с официального сайта Национального центра по мониторингу инновационной инфраструктуры научно-технической деятельности и инновационных систем, дополнены данными региональных центров кластерного развития.

В итоге выявлено, что в 45 регионах России (53\% от их общего числа) созданы 155 территориальных кластеров. Деятельность данных элементов инновационной инфраструктуры регулируют как федеральные, так и региональные нормативно-правовые акты.

Наибольшее число кластеров создано в г. Санкт-Петербург. Центр кластерного развития (ЦКР) г. Санкт-Петербург как структурное подразделение АО «Технопарк Санкт-Петербурга» в настоящее время курирует деятельность 12 территориальных кластеров: информационных технологий и радиоэлектроники, медицинской и фармацевтической промышленности, композитный, транспортного машиностроения, станкоинструментальной промышленности, чистых технологий для городской среды, развития инноваций в энергетике и промышленности, ювелиров, «Транспортное и инфраструктурное строительство», водоснабжения и водоотведения, «Автопром Северо-Запад», объединенный кластер «Инноград науки и технологий».

Вторую позицию по числу созданных кластеров занимают Воронежская область и Республика Татарстан. На их территории функционируют по 8 инновационных территориальных кластеров. На третьем месте - г. Моск- ва и Ростовская область - по 7 инновационных территориальных кластеров.

В 40 регионах России (47 \% от их общего числа) территориальные кластеры на текущий момент либо не созданы, либо имеется только инициатива их создания.

На сегодняшний день кластерная стратегия является одним из эффективных инструментов государственной политики по повышению конкурентоспособности экономики с широким использованием научно-инновационного потенциала [7; 9]. Образование и развитие кластеров позволит за счет использования положительного эффекта синергии обеспечить мультипликативный эффект развития экономики каждого конкретного региона и страны в целом.

Одним из инструментов связи факторов в кластере выступают научные и технологические парки, которые позволяют объединять разрозненные инновационные ресурсы предприятий и вузов.

Установлено, что на текущий момент создано 137 технопарков в 46 регионах России (54\% от общего числа регионов). По количеству таких объектов первое место занимает г. Москва, где работает 31 технопарк, что составляет почти четверть всех созданных в России технопарков. Следующие позиции, как и по числу кластеров, занимают Республика Татарстан и Воронежская область, в них работают 7 и 6 объектов инновационной инфраструктуры соответственно. 43 региона имеют 5 и менее таких объектов. В 39 регионах данные структуры отсутствуют.

Одним из показателей результата, характеризующим коммуникации и коллаборации между исследователями, а также эффективную коммерциализацию исследований и разработок по субъектам Российской Федерации, является инновационная активность организаций.

Анализ данных официального сайта Федеральной службы государственной статистики за 2016 г. показал, что организации 29 регионов России (34 \% от общего числа регионов) имеют инновационную активность выше, чем в среднем по России $(8,4 \%)$.

Наибольшую инновационную активность (более $20 \%$ ) продемонстрировали организации Чувашской Республики (24,5 \%), Республики Татарстан $(21,3 \%)$ и Пензенской облас- 
ти (20,1\%), наименьшую (менее $1 \%$ ) - организации Карачаево-Черкесской $(0,8 \%)$ и Чеченской $(0,3 \%)$ республик.

В последнее десятилетие ввиду повышения внимания государства и научного сообщества к связям между наукой и бизнесом университеты во многих странах стали массово выходить за рамки своих традиционных функций - образовательной и исследовательской - и продвигать академическое предпринимательство [2; 16]. Примером реализации академического предпринимательства в России являются созданные при вузах малые инновационные предприятия (МИП) [3; 10]. Число созданных МИП является показателем результата, обеспечивающим коммерциализацию НИОКР и характеризующим активность их инновационной деятельности.

По данным официальной базы «Учет и мониторинг малых инновационных предприятий научно-образовательной сферы» Минобрнауки России, по всем регионам России создано 2429 МИП (по реестру 2017 г. учтены только действующие при университетах МИП).

Наибольшее их число работает в г. Москве (248) и г. Санкт-Петербурге (161). Значительная доля МИП находится вне Москвы и Санкт-Петербурга, что говорит о развитии малого инновационного предпринимательства и в регионах. Следует отметить Белгородскую и Томскую области - по 123 и 115 МИП соответственно. Меньше всего МИП (по 1) создано в Смоленской и Архангельской областях, Карачаево-Черкесской Республике, республиках Алтай и Тыва, Камчатском крае. В Ненецком, Ямало-Ненецкий и Чукотском автономных округах, Республике Ингушетия, Магаданской и Еврейской автономной областях данные структуры не выявлены.

В результате анализа данных с официального сайта «Мегагранты» получено совокупное количество победителей конкурсов мегагрантов, проводимых в соответствии с Постановлением Правительства Российской Федерации № 220, за весь период проведения конкурса по каждому региону России. Данный показатель свидетельствует о конкурентоспособности региона по реализации крупных исследовательских проектов, организации научных коллабораций, взаимодействии с профильными предприятиями.
За весь период проведения конкурса по России получено 236 мегагрантов. Из них 73 мегагранта получили вузы и научные организации г. Москвы. Среди московских вузов МГУ имени М.В. Ломоносова становился обладателем мегагрантов 14 раз. Дополнительно следует отметить вклад таких национальных исследовательских университетов, как МИФИ и Высшая школа экономики (по 7 мегагрантов).

Вузы Санкт-Петербурга одерживали победу в конкурсе мегагрантов 73 раза, Нижегородской области -22 , Новосибирской -21 , Московской - 15 и Томской -12 . Университеты 24 регионов России становились победителями менее 10 раз. В 55 регионах нет победителей конкурсов на получение грантов Правительства Российской Федерации для государственной поддержки научных исследований, проводимых под руководством ведущих ученых в российских вузах.

Следующим показателем, который демонстрирует возможности научных коллабораций, является количество победителей конкурса по развитию кооперации российских вузов, научных учреждений и производственных предприятий.

Анализ данных официального сайта «Развитие кооперации российских вузов, научных учреждений и производственных предприятий» позволил установить количество победителей по каждому региону за весь период проведения конкурса.

Лидером по развитию кооперации высших учебных заведений, научных учреждений и производственных предприятий является г. Москва (90 комплексных проектов-победителей). Далее следуют такие регионы, как г. Санкт-Петербург (39 проектов), Республика Татарстан (25 проектов) и Московская область (24 проекта). В 34 субъектах Российской Федерации нет проектов-победителей данного конкурса.

Наилучшим стимулятором развития науки и техники в интересах насыщения рынка товарами являются патенты. Вопрос заинтересованности организаций в приобретении прав на патенты и патентных лицензий (договоров) на использование изобретений, промышленных образцов в настоящий момент является очень актуальным $[1 ; 5 ; 6 ; 8]$. Индикатор числа потенциально коммерциализируемых патентов 
характеризует созданные в регионе объекты интеллектуальной собственности.

В результате анализа данных официальных сайтов Федеральной службы государственной статистики и Федеральной системы мониторинга научных организаций за 2016 г. установлено, что лидирующие позиции по данному показателю занимают г. Москва $(962,48)$, г. Санкт-Петербург $(235,32)$ и Московская область $(148,54)$. Наименьший показатель имеют Ненецкий автономный округ и Республика Тыва - по 0,08. Индикатор числа потенциально коммерциализируемых патентов по Чукотскому автономному округу не установлен.

Результаты анализа данного блока показали, что регионы существенно различаются по интенсивности кооперации между предприятиями, университетами, исследователями и коммерциализации исследований и разработок.

В лидирующую группу по большинству показателей данного блока входят г. Москва, г. Санкт-Петербург, Республика Татарстан и Московская область.

В рамках исследования была проведена комплексная оценка исследуемых характеристик, в основе которой лежит расчет интегрального показателя, для чего исходные данные были первоначально нормализованы с использованием максиминной методики. В расчетах были использованы относительные показатели, обеспечивающие сопоставимость данных и представляющие собой показатели интенсивности исследуемых признаков (соотносятся с количеством организаций, занятых исследованиями и разработками, или количеством исследователей).

Значения субиндексов потенциала $I P_{k}^{j}$ рассчитываются методом расстояний по формуле:

$$
I P_{k}^{j}=\sqrt{\frac{\sum_{i=1}^{n}\left(1-p_{k, j}^{-i}\right)^{2}}{n}}
$$

где $k$ - номер соответствующего тематического блока (фактора) $(k=1, \ldots, 5), n$ - количество показателей, включенных в соответствующий субиндекс потенциала, $j=1, \ldots, N, N$ - число субъектов Российской Федерации, $N=85$.

Аналогично значения субиндексов результата $I R_{k}^{j}$ рассчитываются по формуле:

$$
I R_{k}^{j}=\sqrt{\frac{\sum_{i=1}^{n}\left(1-r_{k, j}^{-i}\right)^{2}}{n}} .
$$

Интегральный показатель рассчитывается как сумма субиндексов. Полученные результаты приведены в таблице 2.

Анализ демонстрирует довольно значительное число регионов с нулевым показателем субиндекса потенциала, что говорит об отсутствии на их территории объектов инновационной инфраструктуры и объединений научно-производственных структур, способствующих кооперациям и коллаборациям в сфере исследований и разработок. Наиболее высокие показатели - в Астраханской, Курганской, Липецкой областях, Республике Саха (Якутия), Пензенской области. Вопросы значения показателей и, соответственно, итоговых значений субиндекса не только лежат в плоскости уровня развития коллаборационных структур на территории, но и сопряжены со спецификой их учета. Очевидно, что правильное представление результатов деятельности и их отображение в базе данных, которая стала основой для формирования информационной базы исследования, обеспечили возможность регионам, априори не являвшимся лидерами в сфере инфраструктуры развития науки и технологий, получить высокие оценки деятельности.

Белгородская, Томская области, Республики Марий Эл, Татарстан, г. Санкт-Петербург стали лидерами по значению субиндекса результата. Отмечается, что значительные показатели Республики Марий Эл в большей степени обусловлены высокой интенсивностью выделенных в процессе анализа показателей, что связано с низким числом организаций, занятых исследованиями и разработками, а также небольшим числом исследователей.

Лидирующие позиции по значению интегрального показателя занимают Астраханская, Белгородская, Липецкая области, Республика Татарстан, Курганская область. Приведенные значения показателей демонстрируют также высокое влияние показателей интенсивности, в первую очередь в Астраханской и Курганской областях. При этом высокая интенсивность полученных результатов свидетельствует о наличии возможностей их тиражирования и распространения для расширения сектора исследований и разработок в этих регионах. 


\section{Интегральная оценка материально-технических и финансовых условий развития научной деятельности в регионах Российской Федерации}

\begin{tabular}{|c|c|c|c|c|c|c|}
\hline Субъект Российской Федерации & $\begin{array}{l}\text { Субиндекс } \\
\text { потенциала }\end{array}$ & Ранг & $\begin{array}{l}\text { Субиндекс } \\
\text { результата }\end{array}$ & Ранг & $\begin{array}{l}\text { Интеграль- } \\
\text { ный индекс }\end{array}$ & Ранг \\
\hline \multicolumn{7}{|c|}{ Центральный федеральный округ } \\
\hline Белгородская область & 0,2160 & 18 & 0,4039 & 1 & 0,5327 & 2 \\
\hline Брянская область & 0,0000 & 60 & 0,1644 & 34 & 0,1644 & 57 \\
\hline Владимирская область & 0,3080 & 8 & 0,2182 & 16 & 0,4590 & 6 \\
\hline Воронежская область & 0,2727 & 13 & 0,2300 & 14 & 0,4400 & 11 \\
\hline Ивановская область & 0,0000 & 60 & 0,1684 & 31 & 0,1684 & 55 \\
\hline Калужская область & 0,2276 & 16 & 0,0863 & 66 & 0,2943 & 34 \\
\hline Костромская область & 0,0000 & 85 & 0,1833 & 26 & 0,1833 & 54 \\
\hline Курская область & 0,0195 & 58 & 0,1336 & 52 & 0,1505 & 62 \\
\hline Липецкая область & 0,3753 & 3 & 0,1422 & 49 & 0,4641 & 5 \\
\hline Московская область & 0,0473 & 50 & 0,1762 & 30 & 0,2151 & 47 \\
\hline Орловская область & 0,2929 & 10 & 0,0933 & 63 & 0,3589 & 18 \\
\hline Рязанская область & 0,0796 & 44 & 0,1557 & 40 & 0,2229 & 44 \\
\hline Смоленская область & 0,2094 & 20 & 0,0697 & 72 & 0,2646 & 37 \\
\hline Тамбовская область & 0,0677 & 48 & 0,1680 & 33 & 0,2243 & 43 \\
\hline Тверская область & 0,0000 & 60 & 0,1396 & 51 & 0,1396 & 67 \\
\hline Тульская область & 0,0000 & 60 & 0,2170 & 17 & 0,2170 & 46 \\
\hline Ярославская область & 0,0770 & 45 & 0,1766 & 28 & 0,2400 & 40 \\
\hline г. Москва & 0,0283 & 55 & 0,2748 & 7 & 0,2953 & 32 \\
\hline \multicolumn{7}{|c|}{ Северо-Западный федеральный округ } \\
\hline Республика Карелия & 0,1647 & 24 & 0,1680 & 32 & 0,3051 & 27 \\
\hline Республика Коми & 0,0289 & 54 & 0,0510 & 78 & 0,0784 & 77 \\
\hline Архангельская область & 0,1455 & 26 & 0,1324 & 54 & 0,2586 & 38 \\
\hline Вологодская область & 0,2894 & 11 & 0,1482 & 45 & 0,3947 & 15 \\
\hline Калининградская область & 0,0268 & 56 & 0,1405 & 50 & 0,1636 & 58 \\
\hline Ленинградская область & 0,0000 & 60 & 0,1528 & 42 & 0,1528 & 61 \\
\hline Мурманская область & 0,1292 & 27 & 0,0634 & 73 & 0,1844 & 53 \\
\hline Новгородская область & 0,3413 & 6 & 0,0798 & 70 & 0,3938 & 16 \\
\hline Псковская область & 0,0000 & 60 & 0,2137 & 19 & 0,2137 & 48 \\
\hline г. Санкт-Петербург & 0,0874 & 38 & 0,2960 & 5 & 0,3575 & 20 \\
\hline Ненецкий авт. округ & 0,0000 & 60 & 0,0513 & 76 & 0,0513 & 80 \\
\hline \multicolumn{7}{|c|}{ Южный федеральный округ } \\
\hline Республика Адыгея & 0,0000 & 60 & 0,1285 & 55 & 0,1285 & 69 \\
\hline Республика Калмыкия & 0,0000 & 60 & 0,1063 & 61 & 0,1063 & 72 \\
\hline Республика Крым & 0,1007 & 34 & 0,0509 & 79 & 0,1465 & 66 \\
\hline Краснодарский край & 0,0221 & 57 & 0,1162 & 58 & 0,1356 & 68 \\
\hline Астраханская область & 0,5225 & 1 & 0,1500 & 43 & 0,5941 & 1 \\
\hline Волгоградская область & 0,0000 & 60 & 0,0837 & 68 & 0,0837 & 75 \\
\hline Ростовская область & 0,1794 & 22 & 0,1764 & 29 & 0,3241 & 25 \\
\hline г. Севастополь & 0,0000 & 60 & 0,1487 & 44 & 0,1487 & 64 \\
\hline \multicolumn{7}{|c|}{ Северо-Кавказский федеральный округ } \\
\hline Республика Дагестан & 0,0803 & 43 & 0,0510 & 77 & 0,1272 & 70 \\
\hline Республика Ингушетия & 0,0000 & 60 & 0,0021 & 85 & 0,0021 & 85 \\
\hline Кабардино-Балкарская Республика & 0,0000 & 60 & 0,1476 & 46 & 0,1476 & 65 \\
\hline Карачаево-Черкесская Республика & 0,0000 & 60 & 0,0146 & 84 & 0,0146 & 84 \\
\hline $\begin{array}{l}\text { Республика Северная Осетия - } \\
\text { Алания }\end{array}$ & 0,0869 & 39 & 0,0887 & 65 & 0,1679 & 56 \\
\hline Чеченская Республика & 0,1090 & 32 & 0,1446 & 48 & 0,2378 & 41 \\
\hline Ставропольский край & 0,0000 & 60 & 0,1541 & 41 & 0,1541 & 59 \\
\hline
\end{tabular}


Окончание таблицы 2

\begin{tabular}{|c|c|c|c|c|c|c|}
\hline Субъект Российской Федерации & $\begin{array}{l}\text { Субиндекс } \\
\text { потенциала }\end{array}$ & Ранг & $\begin{array}{l}\text { Субиндекс } \\
\text { результата }\end{array}$ & Ранг & $\begin{array}{l}\text { Интеграль- } \\
\text { ный индекс }\end{array}$ & Ранг \\
\hline \multicolumn{7}{|c|}{ Приволжский федеральный округ } \\
\hline Республика Башкортостан & 0,1289 & 28 & 0,1973 & 22 & 0,1272 & 70 \\
\hline Республика Марий Эл & 0,0000 & 60 & 0,3519 & 3 & 0,0021 & 85 \\
\hline Республика Мордовия & 0,2102 & 19 & 0,2397 & 12 & 0,1476 & 65 \\
\hline Республика Татарстан & 0,1815 & 21 & 0,3474 & 4 & 0,0146 & 84 \\
\hline Удмуртская Республика & 0,1743 & 23 & 0,1976 & 21 & 0,1679 & 56 \\
\hline Чувашская Республика & 0,0856 & 41 & 0,2739 & 8 & 0,2378 & 41 \\
\hline Пермский край & 0,0696 & 47 & 0,2168 & 18 & 0,1541 & 59 \\
\hline Кировская область & 0,2764 & 12 & 0,1132 & 60 & 0,1272 & 70 \\
\hline Нижегородская область & 0,0910 & 35 & 0,2731 & 9 & 0,0021 & 85 \\
\hline Оренбургская область & 0,0763 & 46 & 0,0786 & 71 & 0,1476 & 65 \\
\hline Пензенская область & 0,3431 & 5 & 0,1620 & 35 & 0,0146 & 84 \\
\hline Самарская область & 0,0901 & 37 & 0,2248 & 15 & 0,1679 & 56 \\
\hline Саратовская область & 0,0308 & 52 & 0,1269 & 56 & 0,2378 & 41 \\
\hline Ульяновская область & 0,0908 & 36 & 0,1836 & 25 & 0,1541 & 59 \\
\hline \multicolumn{7}{|c|}{ Уральский федеральный округ } \\
\hline Курганская область & 0,3986 & 2 & 0,1603 & 36 & 0,4950 & 3 \\
\hline Свердловская область & 0,0318 & 51 & 0,1877 & 24 & 0,2135 & 49 \\
\hline Тюменская область & 0,0162 & 59 & 0,1999 & 20 & 0,2129 & 50 \\
\hline Челябинская область & 0,0819 & 42 & 0,2327 & 13 & 0,2956 & 31 \\
\hline $\begin{array}{l}\text { Ханты-Мансийский автономный } \\
\text { округ - Югра }\end{array}$ & 0,2306 & 15 & 0,0907 & 64 & 0,3004 & 29 \\
\hline Ямало-Ненецкий автономный округ & 0,2929 & 10 & 0,1578 & 39 & 0,4045 & 13 \\
\hline \multicolumn{7}{|c|}{ Сибирский федеральный округ } \\
\hline Республика Алтай & 0,0000 & 60 & 0,0569 & 74 & 0,0569 & 78 \\
\hline Республика Бурятия & 0,1475 & 25 & 0,1598 & 37 & 0,2837 & 35 \\
\hline Республика Тыва & 0,0000 & 60 & 0,0228 & 83 & 0,0228 & 83 \\
\hline Республика Хакасия & 0,0000 & 60 & 0,0414 & 82 & 0,0414 & 82 \\
\hline Алтайский край & 0,2184 & 17 & 0,2644 & 10 & 0,4250 & 12 \\
\hline Забайкальский край & 0,1094 & 31 & 0,1269 & 57 & 0,2224 & 45 \\
\hline Красноярский край & 0,0303 & 53 & 0,2768 & 6 & 0,2987 & 30 \\
\hline Иркутская область & 0,2669 & 14 & 0,1578 & 38 & 0,3826 & 17 \\
\hline Кемеровская область & 0,3205 & 7 & 0,1801 & 27 & 0,4429 & 10 \\
\hline Новосибирская область & 0,0857 & 40 & 0,2541 & 11 & 0,3180 & 26 \\
\hline Омская область & 0,1115 & 30 & 0,1334 & 53 & 0,2301 & 42 \\
\hline Томская область & 0,1070 & 33 & 0,3848 & 2 & 0,4507 & 7 \\
\hline \multicolumn{7}{|c|}{ Дальневосточный федеральный округ } \\
\hline Республика Саха (Якутия) & 0,3527 & 4 & 0,1475 & 47 & 0,4482 & 9 \\
\hline Камчатский край & 0,0000 & 60 & 0,0851 & 67 & 0,0851 & 74 \\
\hline Приморский край & 0,0000 & 60 & 0,1922 & 23 & 0,1922 & 52 \\
\hline Хабаровский край & 0,1128 & 29 & 0,1059 & 62 & 0,2068 & 51 \\
\hline Амурская область & 0,0000 & 60 & 0,1135 & 59 & 0,1135 & 71 \\
\hline Магаданская область & 0,0000 & 60 & 0,0817 & 69 & 0,0817 & 76 \\
\hline Сахалинская область & 0,0653 & 49 & 0,0428 & 81 & 0,1053 & 73 \\
\hline Еврейская авт. область & 0,0000 & 60 & 0,0471 & 80 & 0,0471 & 81 \\
\hline Чукотский авт. округ & 0,0000 & 60 & 0,0515 & 75 & 0,0515 & 79 \\
\hline
\end{tabular}

Примечание. Расчеты авторов.

Очевидно, что специфика расчета показателей, ограничение возможностей прямого учета качественных характеристик коллабораций и коммуникаций в исследовательской среде, а также вопросов коммерциализации исследований и разработок не обеспечивают возможности учесть в полной мере все факторы, оказывающие существенное влияние на полученные результаты. Требуется разработка более широкого статистического инстру- 
ментария, который позволил бы создать условия для получения более четких данных, соответствующих специфическим критериям исследуемых процессов и явлений.

В качестве пути дальнейшего развития коллабораций на региональном уровне важным направлением является закрепление его в государственных программах субъектов Российской Федерации как комплекса мероприятий, связанных с созданием конкурентоспособных научных коллективов в границах территории и коммерциализацией результатов интеллектуальной деятельности. Ярким примером реализации политики интеграции научно-исследовательского и инновационного потенциала на платформе региона является инновационный территориальный кластер «Smart Technologies Tomsk», включающий группы предприятий, научных и образовательных организаций области, объединенных связями сетевого характера, и реализованный в рамках государственной программы «Развитие инновационной деятельности и науки в Томской области».

Другим направлением является развитие коллабораций между университетским и региональным сообществом в рамках программ развития региональных опорных университетов, проектов, реализуемых в рамках приоритетного проекта «Вузы как центры пространства создания инноваций», и др.

\section{СПИСОК ЛИТЕРАТУРЫ}

1. Близнец, И. А. Интеллектуальная собственность в инновационном предпринимательстве / И. А. Близнец, В. Р. Смирнова // Копирайт. - 2016. № 2. - C. 7 .

2. Виссема, Й. Г. Университет третьего поколения / Й. Г. Виссема. - М. : Олимп-Бизнес, 2016. 353 c. - Электрон. текстовые дан. - Режим доступа: http:/ip247.ip-144-217-51.net/b/621134/read (дата обращения: 15.06.2018). - Загл. с экрана.

3. Галиуллин, Р. Ф. Развитие предпринимательства в вузах России / Р. Ф. Галиуллин // Вестник Удмуртского университета. Экономика и право. 2015. - Т. 25, вып. 3. - Электрон. текстовые дан. Режим доступа: http://en.vestnik.udsu.ru/files/ originsl_articles/vuu_15_023_02.pdf(дата обращения: 15.06 .2018$)$. - Загл. с экрана.

4. Коробкина, Ю. Ш. Научные коллаборации: определение, классификации, характеристики
/ Ю. Ш. Коробкина, А. М. Омельченко // Economics: Yesterday, Today and Tomorrow. - 2017. - Vol. 7, iss. 4A. - Электрон. текстовые дан. - Режим доступа: http://www.publishing-vak.ru/file/archiveeconomy-2017-4/8-korobkina.pdf (дата обращения: 20.06.2018). - Загл. с экрана.

5. Леонтьева, В. Интеллектуальная собственность - источник, вектор и система формирования стоимости в экономике / В. Леонтьева // Интеллектуальная собственность. Промышленная собственность. - 2014. - № 10. - С. 68-76.

6. Лидеры в науке, аутсайдеры на рынке / реф. Л. Г. Кравец // Патентное дело. - 2014. № 8. - C. 3-5.

7. Марабаева, Л. В. Исследование наиболее значимых территориальных инновационных кластеров Российской Федерации и перспектив развития их стратегического потенциала в контексте проектного подхода / Л. В. Марабаева, О. А. Соколов, А. Е. Сюваева // Научныи вестник Южного института менеджмента. - 2018. - № 3. - С. 24-31. - Электрон. текстовые дан. - Режим доступа: https://doi. org/10.31775/2305-3100-2018-3-24-31 (дата обращения: 15.06.2018). - Загл. с экрана.

8. Мухопад, В. И. Нужна ли интеллектуальная собственность российской экономике? / В. И. Мухопад // Патенты и лицензии. Интеллектуальные права. -2016. - № 9. - С. $62-66$.

9. Прокопенко, 3. В. Кластерная стратегия регионального развития: сущность, преимущества, практика институционального обеспечения / 3. В. Прокопенко // Региональная экономика и управление : электрон. науч. журн. - 2016. - № 4 (48). - Электрон. текстовые дан. - Режим доступа: https://eee-region.ru/article/ 4846/ (дата обращения: 15.06.2018). - Загл. с экрана.

10. Романович, Л. Малое инновационное предприятие на базе вуза: от идеи к бизнесу / Л. Романович, Е. Евтушенко, А. Долбилов // Мир телекома. - Электрон. текстовые дан. - Режим доступа: http://mirtelecoma.ru/magazine/elektronnaya-versiya/ (дата обращения: 15.06.2018). - Загл. с экрана.

11. Смородинская, Н. В. Сетевые инновационные экосистемы и их роль в динамизации экономического роста / Н. В. Смородинская // Инновации. 2014. - № 7 (189). - С. 27-33. - Электрон. текстовые дан. - Режим доступа: https://inecon.org/docs/ Smorodinskaya-Innovations-2014-07.pdf (дата обращения: 20.06.2018). - Загл. с экрана.

12. Справка «Перспективы развития России в международных научных коллаборациях». - Электрон. текстовые дан. - Режим доступа: http://sntr-rf.ru/ upload/iblock/338/280216_Справка_научные_ коллаборации.pdf (дата обращения: 20.06.2018). Загл. с экрана.

13. Стратегия научно-технологического развития Российской Федерации : утв. Указом Прези- 
дента Российской Федерации от 1 дек. 2016 г. № 642 // Электронный фонд правовой и нормативно-технической документации. - Электрон. текстовые дан. - Режим доступа: http://docs.cntd.ru/ document/420384257 (дата обращения: 20.06.2018). Загл. с экрана.

14. Указ Президента Российской Федерации от 7 мая 2018 г. № 204 «О национальных целях и стратегических задачах развития Российской Федерации на период до 2024 года» // Информационно-правовой портал «Гарант». - Электрон. текстовые дан. Режим доступа: http://www.garant.ru/products/ipo/ prime/doc/71837200/ (дата обращения: 20.06.2018). Загл. с экрана.

15. Факторы инновационной активности регионов России: что важнее - человек или капитал? / С. Земцов, А. Мурадов, И. Уэйд, В. Баринова // Форсайт. - 2017. - Т. 10, № 2. - С. 29-42. - Электрон. текстовые дан. - Режим доступа: https:// foresight-journal.hse.ru/data/2017/06/14/1170590871/ 2-\%D0\%A3\%D1\%8D\%D0\%B9\%D0\%B4-29-42.pdf (дата обращения: 15.06.2018). - Загл. с экрана.

16. Lerner, J. The university and the start-up: Lessons from the past two decades / J. Lerner // Journal of Technology Transfer. - 2005. - № 30 (1/2). - P. 49-56.

\section{REFERENCES}

1. Bliznets I.A., Smirnova V.R. Intellektualnaya sobstvennost $\mathrm{v}$ innovacionnom predprinimatelstve [Intellectual Property in Innovative Entrepreneurship]. Zhurnal «Kopirayt» [Copyright Magazine], 2016, no. 2, p. 7.

2. Vissema Y.G. Universitet tretyego pokoleniya [University of the Third Generation]. Moscow, OlimpBiznes Publ., 2016. 353 p. URL: http://ip247.ip-144-21751.net/b/621134/read (accessed 15 June 2018).

3. Galiullin R.F. Razvitie predprinimatelstva $\mathrm{v}$ vuzah Rossii [TheDevelopment of Entrepreneurship in Russia's Universities]. Vestnik Udmurtskogo universiteta. Ekonomika i pravo [Herald of Udmurt University. Economy and Law], 2015, vol. 25, no. 3. URL: http://en.vestnik.udsu.ru/files/originsl articles/ vuu_15_023_02.pdf(accessed 15 June 2018).

4. Korobkina Yu.Sh., Omelchenko A.M. Nauchnye kollaboratsii: opredelenye, klassifikatsii, kharakteristiki [Research Collaborations: Definition, Classification and Characteristics]. Economics: Yesterday, Today and Tomorrow, 2017, vol. 7, iss. 4A. URL: http://www. publishing-vak.ru/file/archive-economy-2017-4/8korobkina.pdf (accessed 20 June 2018).

5. Leontyeva V. Intellektualnaya sobstvennost istochnik, vektor i sistema formirovaniya stoimosti $\mathrm{v}$ ekonomike [Intellectual Property - the Source, Vector and System of Value Formation in the Economy].
Intellektualnaya sobstvennost. Promyshlennaya sobstvennost [Intellectual property. Industrial property], 2014, no. 10, pp. 68-76.

6. Kravets L.G. Lidery v nauke, autsaydery na rynke [Leaders in Science, Outsiders in the Market]. Patentnoe delo [Patent Practice], 2014, no. 8, pp. 3-5.

7. Marabaeva L.V., Sokolov O.A., Syuvaeva A.E. Issledovanie naibolee znachimyh territorialnykh innovacionnykh klasterov Rossiyskoy Federatsii i perspektiv razvitiya ikh strategicheskogo potentsiala $\mathrm{V}$ kontekste proektnogo podkhoda [Study of the Most Significant Territorial Innovation Clusters of the Russian Federation and Prospects for the Development of Their Strategic Potential in the Context of the Project Approach]. Nauchnyy vestnik Yuzhnogo instituta menedzhmenta [Scientific Herald of the Southern Institute of Management], 2018, no. 3, pp. 24-31. URL: https://doi. org/10.31775/2305-3100-2018-3-24-31 (accessed 15 June 2018).

8. Mukhopad V.I. Nuzhna li intellektualnaya sobstvennost rossiyskoy ekonomike? [Do Intellectual Property is Need to the Russian Economy?]. Patenty $i$ litsenzii. Intellektualnye prava [Patents and licenses. Intellectual rights], 2016, no. 9, pp. 62-66.

9. Prokopenko Z.V. Klasternaya strategiya regionalnogo razvitiya: sushchnost, preimushchestva, praktika institutsionalnogo obespecheniya [Cluster strategy of regional development: essence, advantages, practice of institutional support]. Regionalnaya ekonomika i upravlenie: elektron. nauch. zhurn. [Regional Economics and Management: Electronic Scientific Journal], 2016, no. 4 (48). URL: https://eeeregion.ru/article/4846/ (data obrashcheniya: 15.06.2018).

10. Romanovich L., Evtushenko E., Dolbilov A. Maloe innovatsionnoe predpriyatie na baze vuza: ot idei k biznesu [A Small Innovative Enterprise on the Basis of a University: From Idea to Business]. URL: http://mirtelecoma.ru/magazine/elektronnaya-versiya/ (accessed 15 June 2018).

11. Smorodinskaya N.V. Setevye innovatsionnye ekosistemy i ikh rol v dinamizatsii ekonomicheskogo rosta [Network Innovative Ecosystems and Their Role in the Dynamization of Economic Growth]. Innovatsii [Innovations], 2014, no. 7 (189), pp. 27-33. URL: https:/ /inecon.org/docs/Smorodinskaya-Innovations-201407.pdf (accessed 20 June 2018).

12. Spravka "Perspektivy razvitiya Rossiiv mezhdunarodnykh nauchnykh kollaboratsiyakh" [Reference "Prospects for the Development of Russia in International Scientific Collaborations"]. URL: http://sntrrf.ru/upload/iblock/338/280216_Spravka_nauchnye_ kollaboracii.pdf(accessed 20 June 2018).

13. Strategiya nauchno-tekhnologicheskogo razvitiya Rossiyskoy Federatsii: utv. Ukazom Prezidenta Rossiyskoy Federatsii ot 1 dek. $2016 \mathrm{~g}$. № 642 [Strategy for Scientific and Technological 
Development of the Russian Federation: Approved by Decree of the President of the Russian Federation of 1 December 2016 No. 642]. URL: http://docs.cntd.ru/ document/420384257 (accessed 20 June 2018).

14. Ukaz Prezidenta Rossiyskoy Federatsii ot 7 maya 2018 g. № 204 «O nacionalnykh tselyakh i strategicheskikh zadachakh razvitiya Rossiyskoy Federatsii na period do 2024 goda» [Decree of the President of the Russian Federation No. 204 of May 7, 2018 “On National Goals and Strategic Tasks for the Development of the Russian Federation until 2024"']. URL: http://www.garant.ru/ products/ipo/prime/doc/71837200/ (accessed 20 June 2018).
15. Zemtsov S., MuradovA., Wade I., Barinova V. Faktory innovatsionnoy aktivnosti regionov Rossii: chto vazhnee - chelovek ili kapital? [Factors of Innovation Activity in Russian Regions: What is More Important - a Person or Capital?]. Forsait [Foresight], 2017, vol. 10, no. 2, pp. 29-42. URL: https://foresightjournal.hse.ru/data/2017/06/14/1170590871/2$\%$ D0\%A3\%D1\%8D\%D0\%B9\%D0\%B4-29-42.pdf (accessed 15 June 2018).

16. Lerner J. The University and the Start-up: Lessons from the Past Two Decades. Journal of Technology Transfer, vol. 30 (1/2), pp. 49-56.

\section{Information about the Authors}

Natalya E. Barsukova, Senior Researcher of Department of Scientific Research, Tver State University, Zhelyabova St., 33, 170100 Tver, Russian Federation, starey1951@yandex.ru, https://orcid.org/ 0000-0002-9998-389X

Elena V. Klyushnikova, Senior Researcher of Department of Scientific Research, Tver State University, Zhelyabova St., 33, 170100 Tver, Russian Federation, stanislav219@yandex.ru, https://orcid.org/ 0000-0002-6069-7036

Anna A. Maltseva, Candidate of Economic Sciences, Associate Professor, Director of Lurye Scientific and Methodological Center for Higher School Innovative Activity, Tver State University, Zhelyabova St., 33, 170100 Tver, Russian Federation, 80179@list.ru, https://orcid.org/0000-0003-4347-5586

Nadezhda N. Bedenko, Doctor of Economic Sciences, Associate Professor, Head of Department of Enterprie Economics and Management, Tver State University, Zhelyabova St., 33, 170100 Tver, Russian Federation,Bednad@mail.ru, https://orcid.org/0000-0002-2808-1303

\section{Информация об авторах}

Наталья Евгеньевна Барсукова, старший научный сотрудник УНИ, Тверской государственный университет, ул. Желябова, 33, 170100 г. Тверь, Российская Федерация, starey1951@yandex.ru, https://orcid.org/0000-0002-9998-389X

Елена Валерьевна Клюшникова, старший научный сотрудник УНИ, Тверской государственный университет, ул. Желябова, 33, 170100 г. Тверь, Российская Федерация, stanislav219@yandex.ru, https://orcid.org/0000-0002-6069-7036

Анна Андреевна Мальцева, кандидат экономических наук, доцент, директор Научно-методического центра по инновационной деятельности высшей школы им. Е.А. Лурье, Тверской государственный университет, ул. Желябова, 33, 170100 г. Тверь, Российская Федерация, 80179@list.ru, https://orcid.org/0000-0003-4347-5586

Надежда Николаевна Беденко, доктор экономических наук, доцент, заведующий кафедрой экономики предприятия и менеджмента, Тверской государственный университет, ул. Желябова, 33, 170100 г. Тверь, Российская Федерация, Bednad@mail.ru, https://orcid.org/0000-0002-2808-1303 